\title{
Family Libraries and School Success of Pupils*
}

\author{
Vlasta Cabanova, Vladimira Zemancikova \\ University of Zilina, Zilina, Slovakia
}

\begin{abstract}
Reading climate in the family is a determinant how to create relation of a child to the book, his motivation to read, interest and generally to create a base of reading literacy, which develop a person's ability to learn to learn at a later stage, and thus has a major impact on the school.

Keywords: reading books, books, ownership of books, literacy and education, education of parents, school success, school results, educational ambitions, degree of the education achieved
\end{abstract}

\section{Introduction}

Social environment of the child plays a key role in this process, while the family has an irreplaceable position at the early childhood development in relation to the book reading competence (Cabanova, 2004; 2005). The above mentioned can be justified by the theory of mediated learning which is based on the socio-cultural contexts of the learning process and associated with the name of R. Feuerstein. However, he assigns far greater importance of other persons around children in teaching situations, where these important persons mediates child the knowledge of the world. Reading is not a "lonesome" activity (Garbe, 2008), but vice versa: biographical development of stable reading performance is dependent on the support of social and communication contexts, i.e., personal relationships. Considering the development of reading performance there are two crucial critical phases, in particular (Garbe, 2008; Graf, 1993), where building a stable motivation to read is referred to on external support contexts (Graf, 1993), earmarked as a "primary" and "secondary literary initiation".

Family and family environment can arouse interest of the child in the study and further progress. "Everything influences and changes him/her from birth to adulthood. And especially the first experiences are those which are the most important in human life" (Dzuriakova, 2014).

The conditions of own family play a key role in the life chances of children and their learning performance in school. Through activities, such as visiting libraries, concerts, art galleries, theatres, museums, access to books, classical music and other sources in the home, cultural capital of parents establishes intellectual climate for the aspirations and motivation of children and their performance in school. Simply, cultural capital represents the quality of home environment and time parents spend with their children (Bodnarova, Dzambazovic,

\footnotetext{
${ }^{*}$ The article was made a part of the analysis within the project VEGA No. 14/0137/08 under the title "Cultural and social context of family education in changes in the Slovak regional (mainly rural Liptov) community and its community school in comparation with urban elementary school" (head of project: doc. Vlasta Cabanova).

This paper has been written with the support of European Social Fund, project Innovation and internationalization of Education - instruments to increase the quality of the University of Zilina in the European educational area. ITMS code 26110230079. Modern Education for the Knowledge Society/Project is funded by EU.

Vlasta Cabanova, Ph.D., Faculty of Humanities Science, University of Zilina.

Vladimira Zemancikova, Ph.D., Faculty of Humanities Science, University of Zilina.
} 
Gerbery, Filadelfiova, Holubova, \& Porubanova, 2014). According to P. Bourdieu, the amount of social status given by the size of parents' property is not decisive for the success of a student in the school, but the characteristics of the social environment are the key, which are connected with this status, such as the ability to express in the way, the overall style of behavior, width of the cultural horizons... (Keller \& Tvrdy, 2008).

The initial theory of the research was the theory of cultural capital, which was more considerably enforced as a sociological concept thanks to P. Bourdieu and J. Passeron (1977). Bourdieu distinguished three forms of cultural capital-embodied (competences of individual obtained in the course of socialization process), institutionalized (academic titles ...) and objectified (possession of cultural artefacts, e.g., in the form of books, paintings, sculptures, etc.). A book, as one of the forms of cultural capital objectified, was the main variable of the research: we focused on a number of books in the family and content specialization of family library, in particular, we monitored parental and personal library of the child. In particular, we were interested in the existence of the relationship between children's access to books was at home and their school success rate.

\section{Research of Family Library of the Pupil in the Case of Liptov Region}

The aim of the research was to examine the relationship of the family library to the school's success of a pupil in the Liptov region; we examine the school success, in particular, its performance depending on the size of the family library and its content specialisation, where we differentiate parental from personal library of the child. Secondary, we tried to find what characteristics - potentially responsible for school performance of a pupil — the families with a "rich" library will be different from families with "poor" library, i.e., membership to the socio-economic class, differences in the educational ambitions towards their children.

On the basis of the above, we have raised the following questions: Is there a relationship between the size of the family library (parental and personal library of the child) and school success of pupil? Are there differences in the content specialisation of the parental library among pupils with different level of school success? Is the size of the parental library and its content specialisation related to the membership of family to socio-economic class? Are there differences in the educational ambitions among parents with "rich" and "poor" library? Are the families different in consideration of the size of their library in participation of children in the organized leisure activity? Are there differences among the families with "poor" and "rich" library in the amount of funds spent on leisure activities of a child?

We understood school success in the strict sense, i.e., as a pupil meets the performance requirements of the school. The indicator of the school's success represented the average marks calculated from year-end classification of the subjects - mathematics, Slovak and foreign language. With respect to the average marks of the Slovak language, mathematics and foreign language, we have distinguished three categories of marks as follows: excellent (1-1.5), average (1.6-3) and poor marks (3.1-5). In the context of data-collection methods we have used research tool-Questionnaire of family cultural capital. We have processed data using statistical computer programme-Statistical package for social sciences. Considering the nature of research variables in the context of statistical interference methods we have chosen Chi-squared test of independence and the PivotTable sign diagram.

Research file. In the following text, the data analysed come from the research of cultural capital of Liptov families, which was carried out during the months of May to June 2010. According to the statistics total of 1.9.2009 of the Department of Statistics of the Educational Office of Zilina, our basic set represented 2,400 families in total. There were 1,250 questionnaires distributed in total for parents of pupils in Liptov, where 770 
were fulfilled ${ }^{1}$. Where partial analysis, total number of respondents may vary, which is the reason for the incompleteness of the replies to the questionnaire questions. We have interpreted the following data at the level of Liptov region, however, the results are inspiring for the whole territory of Slovakia.

\section{Research Results and Their Interpretation}

Based on the theory of cultural capital (Bourdieu \& Passeron, 1977) and secondarily from family investment theory (Conger \& Dogan, 2007; Conger \& Donnellan, 2014) ${ }^{2}$ we assume that the size of family library and its diversity of content will be in relation to the child's school performance. Given the first hypothesis, we put an average student marks in Liptov in relation with the extent of parental library. We assumed that the average student mark is related to the size of parental library and in the sense that the more extensive the parental library is in the number of books, the greater the proportion of pupils with excellent marks.

Table 1

Average Student Marks, Depending on the Extent of Parental Library_Sign Diagram

\begin{tabular}{|c|c|c|c|c|}
\hline \multirow{3}{*}{ The extent of parental library } & \multicolumn{3}{|c|}{ Average marks } & \multirow{3}{*}{$\sum$} \\
\hline & Excellent marks & & Excellent marks & \\
\hline & (better than 1.6) & & (Better than 1.6) & \\
\hline \multirow[t]{3}{*}{$0-20$ books } & 11 & $0-20$ books & 11 & 80 \\
\hline & $13.75 \%$ & & $13.75 \%$ & $100 \%$ \\
\hline & $(-2.09)-$ & & $(-2.09)-$ & \\
\hline \multirow[t]{3}{*}{$21-100$ books } & 89 & 21-100 books & 89 & 354 \\
\hline & $25.1 \%$ & & $25.1 \%$ & $100 \%$ \\
\hline & $(-0.17)$ & & $(-0.17)$ & \\
\hline \multirow[t]{3}{*}{$101-300$ books } & 56 & $101-300$ books & 56 & 202 \\
\hline & $27.7 \%$ & & $27.7 \%$ & $100 \%$ \\
\hline & $(+0.6)$ & & $(+0.6)$ & \\
\hline \multirow[t]{3}{*}{ More than 300 books } & 27 & More than 300 books & 27 & 79 \\
\hline & $34.2 \%$ & & $34.2 \%$ & $100 \%$ \\
\hline & $(+1.51)$ & & $(+1.51)$ & \\
\hline$\sum$ & 183 & $\sum$ & 183 & 715 \\
\hline
\end{tabular}

The $\chi^{2}$ test of independence represented the statistical test criterion and PivotTable sign diagram ( $z$-score) for the interpretation of the relationship established. Data for statistical verification are as follows: $\chi^{2}=25.24 ; p$ $<0.05\left(p=0.0003^{* * *}\right)$. Data measured support the hypothesis we assumed the relationship between the average school marks of the child and the extent of parental library. At the level of statistical significance using the $z$-scores values we have found that the number of pupils from the families observed with a low number of books (0-20) with poor school marks is significantly higher than expected frequency at the level of significance of 0.001 , while the observed frequency of pupils from the families with low number of books with excellent marks is, on the contrary, significantly lower than expected (significance level of 0.05 ). We find that there is significantly greater number of children with poor marks in the families with an insufficient number of books and, on the other hand, children with excellent marks belong to the families with low number of books.

\footnotetext{
${ }^{1}$ Gender-mixed respondents - questionnaire was designed for one of the parents, irrespective of his gender.

2 Theory is more clear in section "The size of parental library and organized leisure activities of the child".
} 
Family library is not enough to analyze only in quantitative point of view, it is useful to examine its content specialisation as well. The presence of a large number of books itself in the family is not only important, but also their diversity mediating child different areas of knowledge of the world. The above mentioned relates to the function the family assigns to the book - book as a source of relaxation, entertainment, or knowledge, or just as a stylish accessory in the living room. Therefore, we compare parental libraries further considering whether there are differences in the content specialisation of family library for students at different level of school success, i.e., students with excellent, average and poor marks from mathematics, Slovak and foreign language. Statistical test criterion selected - Test of independence $\chi^{2}$ and PivotTable sign diagram.

Data measured confirmed our assumption that there are differences in the content specialisation of parental library for students with different average marks. We have seen these differences on the level of statistical significance in the context of categories of educational and relaxing literature. Within educational literature - where we classified literature about art, geographical maps, atlases, literature of humanities and social sciences, technical and medical/biological literature-we have captured significant differences in the following categories (results of the test of independence $\chi^{2}$, in other interpretations, we start from values of $z$-score): literature on $\operatorname{art}\left(\chi^{2}=8.46 ; p<0.05 ; p=0.014^{*}\right)$ - there is significantly less often found literature on art in the parent library of children with poor average marks compared to children with better marks, geographical maps, atlases, encyclopaedias $\left(\chi^{2}=23.86 ; p<0.05 ; p=0.000^{* * *}\right)$-children with poor marks belong significantly more often to families who have indicated that their family library does not have geographical maps, atlases and encyclopaedias, while children with excellent school marks belong significantly less often to families without geographical maps and atlases; literature of humanities and social sciences $\chi^{2}=$ 9.13; $p<0.05 ; p=0.01^{* *}$ ) - literature stated is less often in parental libraries for children with poor marks. We have not measured significant difference in the other two categories of educational literature, i.e., technical, medical/biological. We have also registered minor differences in the specialisation of parental library for children with different average marks within relaxing literature. Relaxing literature included ancient literature, including ancient myths, medieval fiction, fiction from the period of humanism and the Renaissance, fiction of 17th-19th century, fiction of 20th century and relaxing literature of the 20th century. We registered significant differences only in two categories within relaxing literature in the students with different school marks, namely fiction of the 20th century $\left(\chi^{2}=7.93 ; p<0.05 ; p=0.019^{*}\right)$ - again, to the detriment of students with poor marks and relaxing literature of 20th century $\left(\chi^{2}=7.68 ; p<0.05 ; p=0.0215^{*}\right)$, which parental libraries of students have available in a larger number.

The results suggest the existence of a relationship between the child's marks and the size of parental library, while we also found significant differences with regard to the content specialisation of books in families of students with different school success. The parent libraries of students with poor marks are often lacking literature on art, literature of humanities and social sciences, geographical maps, atlases and encyclopaedias.

The size of parental library is logically related to the size of a child's personal library, parents attributing importance of the book will consciously mediate this attitude further to their descendants, and one of the ways is the foundation of the child's personal library. If we confirmed there is the relationship between the size of parental library of child and his marks, we logically conclude that the relationship shall mutually apply with 
regard to the child's personal library. ${ }^{3}$ From the data measured, we confirmed that the size of the child's personal library is related to the average marks $\left(\chi^{2}=32.51 ; p<0.05 ; p<0.001^{* * *}\right)$. We can find significant differences between the size of the child's personal library and his marks in the category of inadequate library ( $0-10$ books) and extensive library (over 20 books). Children whose parents do not constitute sufficient library (size of personal library up to 10 books) achieve significantly more frequently poor school marks $(z$-score $=$ $4.4+++$ ), while they are significantly less often included in the category of children with excellent marks $(z$-score $=-2.48--)$. On the contrary, children with more extensive personal library (more than 20 books) belong significantly less often to children with poor school marks $(z$-score $=-2.1-)$.

\section{Parental Library Depending on the Socio-Economic Status}

Now, we return to the relationship - the size of parental library and the average marks of the child, whose existence needs to be further clarified. It is based on the previous results that the families with richer library in the extent and content create better conditions for their children for their school performance. There appears the question then, which other aspects, potentially resulting in child's school performance; the families are different in with a rich library from families with poor library. Socio-economic status of the family is considered one of the determining factors. It foundation comprises social layer (class) the individual belongs to, namely on the basis of occupational prestige, income/wealth and level of education achieved, while stressing that the status correlates significantly with a number of indicators of personality, performance, career and life success of self-assertion (Helus, 2007)...

In relation to the subject of this study, the families, given the socio-economic class, varies in different readership background they offer to their descendants. Families with higher socio-economic backgrounds usually create a favourable readership background, and that's the very existence of libraries richer in the extent and content, parents' reading interests, interviews of parents with children on reading, shared reading, etc. According to Gabala and Helšusová (2014), when cumulating higher income, educational and cultural standards of the family, children have the best chance to reach a book and reading. Authors even named reading as one of the mechanisms of intergenerational transmission of inequality and educational and cultural capital of the family. With respect to children's access to books, the pair of authors indicated education of parents as the strongest element of socio-economic background of family, while parents mediate their knowledge capital indirectly to their descendants, and that they themselves read and create family reading motivating background, they read children and speaks to the children on reading, their households are equipped with plenty of books, are eligible to motivate a child for the book, or choose him a suitable book. Similarly, towards higher professional positions, there is an increasing probability that parents will be able to motivate their children in reading. Family income is also important, given the possibility of family to spend means to reading important elements of household items (such as books, library...). Appropriately, however, the authors noted that higher-income families are mostly families with higher education and higher professional position, i.e., those who often regard book and work with information important (Bacova \& Lelakova, 2014).

On the basis of the foregoing we ask whether there is a relationship between the size of parental library and membership of family to socio-economic class, i.e., what are the SES indicators where the families are different with few books from families with a rich library? When the indicators of family membership to

\footnotetext{
${ }^{3}$ Given the number of books in the personal library of the child, we have defined the three categories: library with a range of $0-10$ books; 11-20 books and library with more than 20 books.
} 
socio-economic class will, for the purposes of our research, be education, occupational prestige, and family income.

We have found that families, given the extent of parental library, differ in important indicators of socio-economic status, particularly of education achieved - poor parental library (0-20 books) was significantly more common among respondents with elementary $(z$-score $=4.32+++)$ and secondary education school leaving examination $(z$-score $=3.67+++)$ and, on the other side, rich library (over 300 books) were significantly more frequently associated with university education of respondents $(z$-score $=4.34+++)$. Considering professional status, a rich library (over 300 books) referred to respondents with higher professional positions $(z$-score $=3.55+++)$. Family income has also proved to be significant, strong family library is often associated at the level of statistical significance with respondents with higher incomes $(z$-score $=2.12+++)$. Students from families with "rich" library more often have at least one parent with higher education and higher professional status, while often come from higher income households. The results are presented in Table 2.

Table 2

Extent of Parental Libraries Depending on the Indicators of Socioeconomic Status-Sign Diagram

\begin{tabular}{|c|c|c|c|c|c|c|c|c|c|}
\hline \multirow{3}{*}{ Education achieved } & \multicolumn{6}{|c|}{ Extent of family library } & & & \\
\hline & $0-20$ & & $21-100$ & & $101-300$ & & \multicolumn{3}{|c|}{ More than 300 books } \\
\hline & (n) & $(\%)$ & $(n)$ & $(\%)$ & $(n)$ & $(\%)$ & $(n)$ & $(\%)$ & $\sum$ \\
\hline \multirow[t]{2}{*}{ Elementary } & 11 & $42.3 \%$ & 11 & $42.3 \%$ & 1 & $3.8 \%$ & 3 & $11.5 \%$ & $100 \%$ \\
\hline & $(4.32)+++$ & & $(-0.47)$ & & $(-2.32)-$ & & $(-0.09)$ & & \\
\hline \multirow[t]{2}{*}{$\begin{array}{l}\text { Secondary without } \\
\text { examination }\end{array}$} & 51 & $20.6 \%$ & 128 & $51.8 \%$ & 59 & $23.9 \%$ & 9 & $3.6 \%$ & $100 \%$ \\
\hline & $(3.67)+++$ & & $(+0.67)$ & & $(-1.18)$ & & $(-3.48)---$ & & \\
\hline Complete secondary & $\begin{array}{l}27 \\
(-2.65)--\end{array}$ & $7.5 \%$ & $\begin{array}{l}187 \\
(+0.87)\end{array}$ & $51.9 \%$ & $\begin{array}{l}105 \\
(+0.48)\end{array}$ & $29.2 \%$ & $\begin{array}{l}41 \\
(+0.23)\end{array}$ & $11.4 \%$ & $100 \%$ \\
\hline University & $\begin{array}{l}6 \\
(-2.57)-\end{array}$ & $4.5 \%$ & $\begin{array}{l}47 \\
(-2.16)-\end{array}$ & $35.6 \%$ & $\begin{array}{l}48 \\
(+1.87)\end{array}$ & $36.4 \%$ & $\begin{array}{l}31 \\
(+4.34)+++\end{array}$ & $23.5 \%$ & $100 \%$ \\
\hline \multicolumn{10}{|l|}{ Professional status } \\
\hline Manual and semi-routine & $\begin{array}{l}54 \\
(+0.65)\end{array}$ & $12.8 \%$ & $\begin{array}{l}225 \\
(+1.2)\end{array}$ & $53.2 \%$ & $\begin{array}{l}109 \\
(-0.79)\end{array}$ & $25.8 \%$ & $\begin{array}{l}35 \\
(-1.97)\end{array}$ & $8.3 \%$ & $100 \%$ \\
\hline Middle position & $\begin{array}{l}17 \\
(-1.19)\end{array}$ & $8.8 \%$ & $\begin{array}{l}89 \\
(-0.64)\end{array}$ & $45.9 \%$ & $\begin{array}{l}61 \\
(-0.97)\end{array}$ & $31.4 \%$ & $\begin{array}{l}27 \\
(-1.03)\end{array}$ & $13.9 \%$ & $100 \%$ \\
\hline Higher positions & $\begin{array}{l}3 \\
(-1.14)\end{array}$ & $6,1 \%$ & $\begin{array}{l}12 \\
(-2.46)--\end{array}$ & $24.5 \%$ & $\begin{array}{l}20 \\
(+1.73)\end{array}$ & $40.1 \%$ & $\begin{array}{l}14 \\
(+3.55)+++\end{array}$ & $28.6 \%$ & $100 \%$ \\
\hline Unemployed, pensioners & $\begin{array}{l}11 \\
-1.45\end{array}$ & $18.0 \%$ & $\begin{array}{l}31 \\
(-0.19)\end{array}$ & $50.8 \%$ & $\begin{array}{l}12 \\
(-1.2)\end{array}$ & $19.7 \%$ & $\begin{array}{l}7 \\
(-0.01)\end{array}$ & $11.5 \%$ & $100 \%$ \\
\hline \multicolumn{10}{|l|}{ Amount of income } \\
\hline Low-income families & $\begin{array}{l}22 \\
(-1.51)\end{array}$ & $17.5 \%$ & $\begin{array}{l}67 \\
(-0.62)\end{array}$ & $53.2 \%$ & $\begin{array}{l}27 \\
(-1,11)\end{array}$ & $21,4 \%$ & $\begin{array}{l}10 \\
(-1.18)\end{array}$ & $7.9 \%$ & $100 \%$ \\
\hline Middle-income & $\begin{array}{l}44 \\
0.48\end{array}$ & $13.6 \%$ & $\begin{array}{l}162 \\
0.21\end{array}$ & $50.1 \%$ & $\begin{array}{l}84 \\
-0.18\end{array}$ & $26.0 \%$ & $\begin{array}{l}33 \\
-0.67\end{array}$ & $10.2 \%$ & $100 \%$ \\
\hline Higher income & $\begin{array}{l}9 \\
(-2.14)-\end{array}$ & $6,3 \%$ & $\begin{array}{l}63 \\
(-0.9)\end{array}$ & $44.0 \%$ & $\begin{array}{l}46 \\
(+1.31)\end{array}$ & $32.2 \%$ & $\begin{array}{l}25 \\
(2.12)++\end{array}$ & $17.5 \%$ & $100 \%$ \\
\hline
\end{tabular}

However, parents from different socio-economic classes are not different only in the number of books contained in the library, but also the structure of the parent library by periods and genres. Therefore, we compared the parental libraries for parents of students from different socio-economic classes, given the content 
specialisation of the library. Logically, education is the strongest SES indicator. To verify the statistical significance of the differences observed, we used the test of independence $\chi^{2}$ and interpreted the relationship further using PivotTable sign diagram ( $z$-score). From the data measured, we found significant differences in the ownership of literature of humanities and social sciences between parents with different level of education: $\chi^{2}=55.997 ; p<0.05\left(p=0.000^{* * *}\right)$, while the category of books is significantly more often found in the libraries of parents with higher education and significantly less frequently in parents with vocational education. We have caught a similar relationship even in books on art: $\chi^{2}=21.06 ; p<0.05\left(p=0.000^{* * *}\right)$, which are also significantly more often found in parents with higher education and significantly less often parents with vocational education. We have also found differences among parents with different education levels in the literature of medical specialisation: $\chi^{2}=13.85 ; p<0.05\left(p=0.0031^{* *}\right)$, considering the level of significance, parents with higher education own books of medical/biological character significantly more frequently compared to other educational categories of parents. The share of technical books increases together with the amount of education: $\chi^{2}=15.1 ; p<0.05\left(p=0.002^{* *}\right)$. We have seen the differences in ownership of geographical maps, atlases and encyclopaedias: $\chi^{2}=26.912 ; p<0.05\left(p=0.000^{* * *}\right)$ that are significantly more frequently absent in the libraries of parents with elementary and vocational education.

\section{The Size of Parental Library and Educational Aspirations of Parents}

The relationship of educational aspirations of parents to the educational success of the child was examined by several authors (Spacek, Safr, \& Vojtiskova, 2010; Katrnak, 2004; Mcloyd, 1998). According to Sewell and Shah (1968), mental abilities and social background are only potential of educational and professional career of a child, which is activated only through aspiration and life plans. The education achieved is mainly determined by the educational aspirations and expectations from the significant social surroundings. The impact of "significant social environment" is important in the process of forming own aspirations. The importance of expectations of adults against children lies in the fact that children interiorise the expectations of parents and other significant adults from their surroundings. Subsequently, words or gestures expressed in expectations reflect in the relevant period of choosing secondary school. In the next section, we have examined the educational ambitions of parents through the perspective of initial findings - in the first hypothesis, we confirmed the relationship of the size of parental library and school marks of the child, searched for answers to the question what are other characteristics where the families with "rich" and "poor" library are different, since these families differ in the extent of school success of children. We determined the educational ambitions of parents as potentially important variable, where their indicator were parents' preferences given the choice of a suitable secondary school for their child. We asked whether there are differences between the parents with "rich" and "poor" in the educational aspirations in respect of its descendants. Therefore, we asked parents question, what type of high school is considered to be the most suitable for their children, while evaluation selection was made from the following high schools: gymnasium, secondary school with teaching field (SOU), secondary school with study field (business, medical, industry, etc.) and an art school. We expected differences in preferences of the parents with respect to the extent of parental library. We assumed that parents with an extensive library will assign greater importance to gymnasium education of children than parents with poorer library. At the same time we expected differences in preferences in relation to secondary school with the teaching profession; we assumed there that parents with poorer library will evaluate this school library more often for the best choice for their children than parents with a rich library. 
The explanation of the relationship between the size of parental library and educational ambitions of parents can be quite prosaic - the size of family library reflects the relationship of family members to a book, its potential to mediate knowledge of the outside world; we can assume that the parents with a rich library assign greater importance to the value of education and, therefore, their expectations for the level of education of their descendants are more ambitious (Lelakova, 2012).

The explanation of the differences in preferences of secondary school between the parents with different extent of parental library can be interpreted through different socio-economic status of the families again. On the basis of the previous results, we know that parents with richer library are more likely to have higher education, occupy a position with a higher status and belong among higher income groups and we meet with higher ambitions in these socio-economic groups in relation to its descendants (higher expectations are already reflected in the preference of suitable high school). Interpretation of the relationship between the size of parental library and educational aspirations of parents using socio-economic status can be documented through research results of T. Katrnak: The author analysed the relationship of educational aspirations and the education achieved with respect to the membership of parents to socio-economic class. The author fittingly named children of labourers (lower class) — with regard to the educational aspirations of the parents — as freely floating plugs, the importance of education is not emphasised too much, children are encouraged to high ambitions, the parents themselves do not expect from them above average results in school. According to Katrnak, parents of this lower class see themselves in children, and the school success was not a part of their identity. It is not important for these parents, whether they will have a high school; they see a greater significance in certificate of apprenticeship (Spacek et al., 2010). The results of other research, however, encourage us not to see an explanation of the relationship between educational ambitions of parents and the size of their library clearly over the socio-economic status. Then it would mean that parents with poor library (= mostly parents of lower socio-economic classes) have lower ambitions, and those are co-responsible for a lower school success of the child. This is, however, valid not for all the parents so-called working families. According to the research of Spacek, Safr and Vojtiskova (Spacek et al., 2010), high ambitions are not connected with university educated parents, but also with so-called "ambitious" working family ${ }^{4}$. We return to the importance of the educational aspirations of the parents once again, which can be independent of socio-economic status of the family. Educational ambitions will turn out to be particularly significant for children from less privileged classes. The above mentioned confirmed the results of the research-Impact of cultural and social capital of the family on the professional status of today's thirties-Husak's children (2008), where the analyses shown that status position of today's thirties were mostly influenced the aspirations of their parents - definition of the study as an important objective and encouraging to it—and school results as well (retrieved from http://blisty.cz/art/57064.html).

Another interpretation of the existence monitoring the relationship, however, offers us through the results of the research with the title "Paretns and Education 2010" (Spacek et al., 2010). Parental ambitions given to the interrelation with the socio-economic class do not escape from the attention of authors. Thedata measured confirmed the statistical significance of the relationship between the frequency of library visits and the evaluation of the suitability of the high school: $\chi^{2}=12.98 ; p<0.05\left(p=0.0047^{* *}\right)$. The increase in frequency of visits to the library grows proportion of parents evaluating gymnasium as a suitable type of high school. There

${ }^{4}$ We pay closer attention to the category of family in part: The marks of the child depending on the attendance of library. 
are significant differences in the category of children visiting the library often ( 5 and more times in the last year), of which up to $79 \%$ of parents identified gymnasium as an appropriate type of secondary school (21\% evaluated it as an inappropriate selection).

\section{Conclusions}

The result of their analysis was the finding that the high educational ambitions of parents to their descendants are not connected with university family. They are immanent to an ambitious working family (determined on the basis of ambition of parents for the future education of their children), where these parents aspire to a university or higher vocational education of their children. However, the ambitions stated do not cover so-called "static" working families. The children of the "ambitious" and "static" working families vary: children of the "ambitious" working families are characterized in better marks, read more and more often go to libraries compared to children from a "static" working family. However, we were not able to explain the ralationship using the membership of the child to the socio-ecomomic class, comparing and analysing the results of the research of three authors-Spacek, Safr, and Vojtiskova (2010) come to explanation of the existence of the relationship through the educational ambitions of parents. On the basis of this research, we compared the frequency of visits to library by children with educational ambitions of parents which indicator was the choice of an appropriate secondary school. We have come to the findings, which confirmed our assumptions.

\section{References}

Bacova, B., \& Lelakova, E. (2014). Development and innovation of curriculum in foreign language. Proc. of INTED 2014, Valencia, 2014, 0163-0169, ISSN 2340-1079.

Bodnarova, B., Dzambazovic, R., Gerbery, D., Filadelfiova, J., Holubova, B., \& Porubanova, S. (2014). Intergenerational reproduction of poverty: Secondary analyses of theoretical concepts and empirical sources (in Slovak) [online]. Bratislava: Stredisko pre studium prace a rodiny. Retrieved May 9, 2014, from http://www.sspr.gov.sk/texty/File/pdf/2005/rodina/Medzigen_repro_chudoby_1.p df

Bourdieu, P., \& Passeron, J. (1977). Reproducion in education, society and culture. London: Sage Publications.

Cabanova, V. (2004). Forming relationship to books in early school age (in Slovak). Slovenskyjazyk a literatura v skole, 50(5-6), $148-152$.

Cabanova, V. (2005). Formative influence as fostering relationship to books in pre-reading and reading periods (in Slovak). Komensky, 130(1), 13-20.

Conger, R., \& Dogan, S. (2007). Social class and socialization in families. Handbook of socialization theory and research (pp. 433-460). New York: Guilford Press.

Conger, R., \& Donnellan, M. B. (2014). An interactionist perspective on the socioeconomic context of human development. [online]. Annual Review of Psychology. Retrieved May 9, 2014, from http://jpkc.ecnu.edu.cn/fzxlx/ jiaoxue/An\%20Interactionist $\% 20$ Perspective $\% 20$ on $\% 20$ the $\% 20$ Socioeconomic\%20Context $\% 20$ of $\% 20$ Human $\% 20$ Develop ment.pdf

Dzuriakova, J. (2014). Teachers and their possibilities of using literary geography in teaching literature (pp. 356-363). Najnovsie trendy a vyzvyeuropskehovyskumu v edukacnychvedach. Trnava: Fakultasocialnych vied UCM. (in Slovak)

Gabal, I., \& Helšusová, L. (2014). What are the reading abilities of Czech children? Analysis of the results of sociological research [online]. Praha: GABAL, Analysis \& Consulting. Retrieved May 9, 2014, from http://www.adam.cz/dokumenty/2006/jak-ctou-ceske-deti.pdf

Garbe, C. H. (2008). Reading in Germany: Topical research results, background and concepts of reading support. In Ctenarstvi, jehovyznam a podpora. Vyzkum,teorie a praxe v Ceske republice a SpolkoverepubliceNemecko (pp. 5-19). Praha: Svazknihovnikuainformacnichpracovníku CR..

Graf, M. (1993). In Garbe, C. H. (2008). Reading in Germany: Topical research results, background and concepts of reading support. In Ctenarstvi, jehovyznam a podpora. Vyzkum,teorie a praxe v Ceskerepublicea SpolkoverepubliceNemecko (pp. 5-19). Praha: SvazknihovnikuainformacnichpracovníkuCR. 
Helus, Z. (2007). Social psychology for educators. Praha: Grada.

Katrnak, T. (2004). Sentenced to manual labour: Educational reproduction in a working-class family (in Czech) (p. 190). Praha: Slon.

Keller, J., \& Tvrdy, L. (2008). Knowledge society? Temple, lift and insurance company (in Czech) (p. 184). Praha: Slon.

Lelakova, E. (2012). The role of the living environment in the process of building up the linguistic picture of the world (pp. 174-179). Zilina: FHV: University of Zilina.

Mcloyd, V. C. (1998). Socio-economic disadvantage and child development. American Psychologist, 53, 185-204.

Spacek, O., Safr, J., \& Vojtiskova, K. (2010). Parents and education 2010 (in Czech), Zaverecna zprava z vyzkumu (p. 22). Praha: Sociologicka ustav AV CR. 